\title{
Occurrence and Distribution in Rwanda of Soilborne Fungi Pathogenic to the Common Bean
}

Gerard Rusuku, Université Nationale du Rwanda, B.P. 117, Butare, Rwanda; Robin A. Buruchara, Great Lakes Regional Bean Program, Centro Internacional de Agricultura Tropical (CIAT), B.P. 259, Butare, Rwanda; Martin Gatabazi, Université Nationale du Rwanda, B.P. 117, Butare, Rwanda; and Marcial A. Pastor-Corrales, Bean Program, CIAT, Apartado Aéreo 6713, Cali, Colombia

\begin{abstract}
Rusuku, G., Buruchara, R. A., Gatabazi, M., and Pastor-Corrales, M. A. 1997. Occurrence and distribution in Rwanda of soilborne fungi pathogenic to the common bean. Plant Dis. 81:445449 .

The occurrence and distribution of soilborne fungi pathogenic to the common bean were determined by surveys conducted in seven of Rwanda's 10 prefectures during four growing seasons from 1989 to 1990 . The pathogens were identified on the basis of symptoms, colony characteristics, reproductive structures, and pathogenicity tests. Of the plants sampled during the March through June 1989 season from four prefectures, 97\% exhibited symptoms associated with soilborne pathogens. Root and hypocotyl symptoms appeared in plants sampled during the September through December 1989 season from the prefectures of Kigali (19\%), Butare (40\%), Gikongoro (33\%), and Cyangugu (33\%) and during the March through June 1990 season from Gisenyi (60\%) and Kibungo (53\%). Pythium spp., Macrophomina phaseolina, Rhizoctonia solani, and Fusarium oxysporum f. sp. phaseoli were isolated from all seven prefectures during all four seasons. Sclerotium rolfsii was isolated only during the 1990 September through December season. The frequency of isolation varied by region and season. Pythium spp. were the most frequently isolated fungi from about $40 \%$ of the samples, suggesting their potential importance in the root rot complex in Rwanda. The relative importance of the soilborne pathogens and possible relationships with existing cropping systems are discussed. These results will help focus efforts in developing management strategies for common bean diseases caused by soilborne pathogens in Rwanda.
\end{abstract}

Additional keywords: Phaseolus vulgaris, root rot

The common bean, Phaseolus vulgaris L., is one of Rwanda's principal crops. It is grown throughout Rwanda by $95 \%$ of the farmers and provides $65 \%$ of the protein and $32 \%$ of the calories in the Rwandan diet $(16,20)$. Crop production is intensive because the human population of the Great Lakes Region (consisting of Rwanda, Burundi, and Kivu Province in extreme eastern Zaire) is relatively large and increasing rapidly and farm sizes are dwindling. As a consequence, soil fertility is declining; fallow periods are almost nonexistent; and rotations, effective in managing diseases, are seldom practiced (10). Studies by Neel et al. in 1976 (17) on 41 soils from different regions of Rwanda showed that $95 \%$ were deficient in nitrogen, $90 \%$ in phosphorus, $66 \%$ in potassium, $19 \%$ in magne-

Corresponding author: Marcial A. Pastor-Corrales E-mail: m.pastor@cgnet.com

Accepted for publication 24 January 1997.

Publication no. D-1997-0228-04R

(C) 1997 The American Phytopathological Society sium, and $50 \%$ in calcium. A similar and more detailed analysis also showed that most soils were low in organic carbon and tended to be acidic (Table 1) (4). Common beans are grown during two or three growing seasons a year, in some cases alone, but generally in seasonal rotation with sorghum or sweet potatoes, the other major annual crops of the region (26). September through December is the main growing season for the common bean, while March through June is the main sorghum-growing season.

Diagnostic studies conducted during 1985 and 1986 identified diseases and low soil fertility as the principal factors limiting common bean production in Rwanda (23). Root rots were identified as one of the five major categories of diseases attacking beans in Rwanda (6). Captan, thiram, and benomyl, used in treating seeds, did not significantly control root rots, either on station or on farm (23). The sudden increase in root rots in common beans is relatively recent (15) and seems to be linked to changes in farming systems and the resulting decline in soil fertility. Several soilborne pathogens cause root rot and bean wilt $(1,2)$; to develop an effective strategy for their management, quantitative data must be gathered on the types of pathogens prevalent, their distribution, and their relative importance. This paper reports the results of surveys in Rwanda from 1989 and 1990.

\section{MATERIALS AND METHODS}

Distribution of soilborne pathogens. Initial surveys were conducted in farmers' fields during the March through June 1989 planting season in the prefectures of Kigali (its actual name is Kigali-Nord), Gikongoro, Cyangugu, and Kibuye (Fig. 1). Severe cases of root rot had been reported in these areas for the September through December 1988 season (7). In each prefecture, three communes (administrative units, each consisting of about 5,000 families) were selected for the survey. Within each commune, three sectors (smaller administrative units, each consisting of approximately 1,000 families) were surveyed. For each sector, three fields of bush, three fields of climbing beans, and three fields chosen at random were sampled. Information for each field was obtained, including area, types of beans grown, time of planting, and previous cropping history. In each field, a plot $10 \times 10 \mathrm{~m}$ was marked within which four $1-\mathrm{m}^{2}$ plots were marked, and all bean plants were carefully dug with a shovel. The roots and hypocotyls were examined for symptoms of soilborne fungal pathogens and nematodes, particularly root knot. Shoots were excised, and hypocotyls with roots were collected and stored at $4^{\circ} \mathrm{C}$ in a refrigerator until they were used for isolation of fungi.

During the September through December 1989 season, the occurrence and distribution of soilborne pathogens in both farmers' and experimental fields were examined throughout the growing season in the prefectures of Kigali, Butare, Gikongoro, and Cyangugu. Three communes per prefecture and three fields per commune were selected for the survey. In each field, 36 plots of $1 \mathrm{~m}^{2}$ were marked in an area of $10 \times 10 \mathrm{~m}$. At planting, nine plots were randomly assigned for each of four growth stages at which sampling would be made (24): V3 (2 to 3 weeks after planting when the first trifoliate leaf opened), R5 (beginning of flowering), R7 (beginning of pod formation), and R9 (physiological pod maturity). At each stage, plants in each $1-\mathrm{m}^{2}$ 
plot were carefully dug, and the roots and hypocotyls were examined for disease symptoms. A sample of 20 plants per square meter was used for isolation of pathogens. Similar surveys were conducted in the prefectures of Gisenyi and Kibungo during the March through June 1990 season.

During the September through December 1990 season, types and prevalence of soilborne bean pathogens were determined on three local bush varieties (Kilyumukwe, Mutiki, and Rubona 5) and 16 entries (A 70, A 295, A 300, BAT 332, BAT 447, BAT 868, CG/82-77, CG/82-79, EMP 81, EMP 86, ICA-Pijao, IPA 1, G 5059, Mortino, RIZ 30, and XAN 112) of the International Bean Root Rot Nursery (IBRRN). The IBRRN is distributed by the Bean Pathology Section of the Centro Internacional de Agricultura Tropical (CIAT), Cali, Colombia, and contains common bean entries with resistance or tolerance to some, but not all, major bean root rot pathogens. The entries, replicated three times per field, were grown at two locations per commune and in three communes for each of the prefectures of Kigali, Butare, Gikongoro, and Cyangugu. Samples were taken at the beginning of flowering (R5); 12 plants per replicate were used for isolation of pathogens.

Diagnosis, isolation, and identification of soilborne pathogens found on beans. Preliminary diagnosis was based on symptoms in shoots, hypocotyls, and roots that are usually associated with specific root rot and wilt pathogens. In all isolations, hypocotyl or root tissues showing symptoms were first washed in running tap water and cut into $1-\mathrm{cm}$ portions. They were then surface sterilized in $1.0 \% \mathrm{NaOCl}$ for 5 min, double rinsed in sterile distilled water, blot dried between sterile paper towels, and plated aseptically on potato dextrose agar acidified with lactic acid ( $2 \mathrm{ml} / \mathrm{liter})$. Plates were then incubated in a growth chamber at 22 to $26^{\circ} \mathrm{C}$ with a 12 -h photoperiod supplied by long, fluorescent, daylight tubes. Plates were examined 7 to 14 days later for fungi associated with the various symptoms observed. Pure cultures were obtained by subculturing. Fungi were identified according to colony characteristics and reproductive structures by using keys and referring to primary $(11,25)$ and secondary genera and species descriptors $(1,2,5)$. The Pythium isolates were identified only at the genus level.

Pathogenicity tests. Pathogenicity tests were conducted on plants grown in a pasteurized soil-sand mixture (4:1) in 20$\mathrm{cm}$ pots in a greenhouse with isolates representative of the different pathogens isolated. The local cultivar Mutiki was inoculated with Pythium spp., Rhizoctonia solani Kühn, Sclerotium rolfsii Sacc., and Macrophomina phaseolina (Tassi) Goidan- ich, and G 2333 was inoculated with $\mathrm{Fu}$ sarium oxysporum Schlechtend.:Fr. f. sp. phaseoli J. B. Kendrick \& W. C. Snyder. Inoculation methods developed at CIAT (2) were used. Two-week-old cultures of Pythium spp. growing on water agar were homogenized for $1 \mathrm{~min}$ in a blender containing a small amount of distilled water, and then this inoculum was placed around the bases of 10-day-old bean seedlings grown in a damp, pasteurized soil-sand mixture. Whole rice seeds were used to produce inocula for M. phaseolina and $R$. solani. Potato dextrose agar disks with 2 week-old cultures of the two fungi were placed in separate flasks containing the autoclaved whole rice seeds and then incubated at 24 to $28^{\circ} \mathrm{C}$ for 3 to 4 weeks. At planting, three to five colonized rice

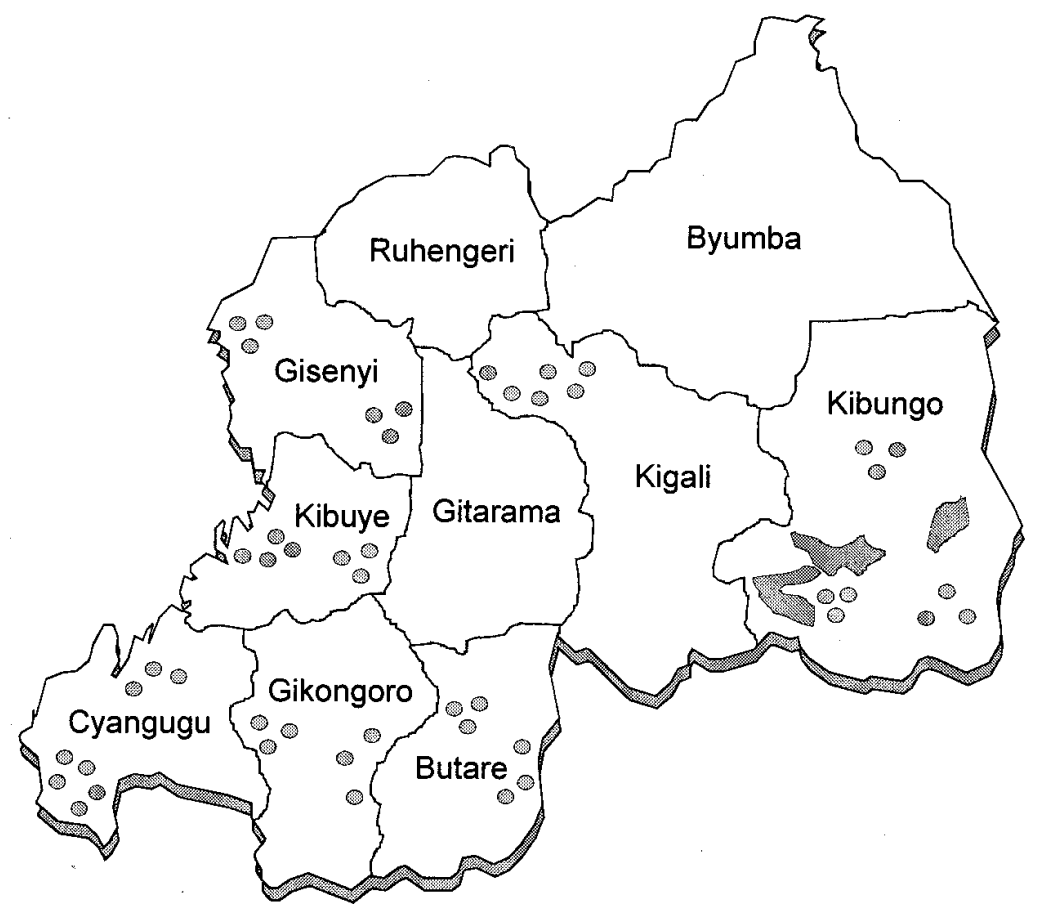

Fig. 1. Rwandan prefectures. Dots indicate locations of communes surveyed for soilborne fungi pathogenic to the common bean.

Table 1. Selected primary characteristics of soil samples from 11 communes in eight prefectures of Rwanda ${ }^{\mathrm{a}}$

\begin{tabular}{|c|c|c|c|c|c|c|c|c|c|c|c|c|c|c|c|}
\hline Prefecture & Commune & $\begin{array}{c}\text { Depth } \\
\text { (cm) }\end{array}$ & $\begin{array}{r}\text { Clay } \\
(\%)\end{array}$ & $\begin{array}{l}\text { Silt } \\
(\%)\end{array}$ & $\begin{array}{c}\text { Sand } \\
(\%)\end{array}$ & $\begin{array}{c}\text { Organic } \\
\text { C } \\
(\%)\end{array}$ & $\begin{array}{c}\text { Total } \\
\mathrm{N} \text { in } \\
<2 \mathrm{~mm}\end{array}$ & $\begin{array}{c}\text { Extr }^{\mathbf{b}} \\
\mathbf{P}\end{array}$ & $\begin{array}{c}\mathrm{Ca}^{\mathbf{c}} \\
(\mathbf{m e q} / \\
100 \mathrm{~g})\end{array}$ & $\begin{array}{l}\mathrm{Mg}^{\mathrm{c}} \\
(\mathrm{meq} / \\
100 \mathrm{~g})\end{array}$ & $\begin{array}{c}\mathrm{K}^{\mathrm{c}} \\
(\mathbf{m e q} / \\
100 \mathrm{~g})\end{array}$ & $\begin{array}{c}\text { Acidity } \\
\text { (meq/ } \\
100 \text { g) }\end{array}$ & $\begin{array}{c}\text { Extr } \\
\text { AL } \\
(\text { meq/ } \\
100 \text { g) }\end{array}$ & $\begin{array}{l}\text { CEC } \\
(\mathrm{meq} / \\
100 \mathrm{~g})\end{array}$ & $\begin{array}{c}\text { pH } \\
\left(\mathrm{H}_{2} \mathrm{O}\right. \\
\mathbf{1 : 1})\end{array}$ \\
\hline Gikongoro & Mabuga & $0-15$ & 39.5 & 7.7 & 52.8 & 3.08 & 0.167 & $\ldots{ }^{d}$ & 0.3 & 0.1 & 0.1 & 19.0 & 3.9 & 12.1 & 4.7 \\
\hline Butare & Mbazi & $0-25$ & 51.8 & 9.8 & 38.4 & 2.24 & 0.162 & $\ldots$ & 0.4 & 0.1 & 0.1 & 16.7 & 4.0 & 12.4 & 4.8 \\
\hline Gitarama & Tambwe & $0-15$ & 39.5 & 7.7 & 52.8 & 3.08 & 0.167 & $\ldots$ & 0.3 & 0.1 & & 19.0 & 3.9 & 12.1 & 4.7 \\
\hline Kigali & Gashora & $0-10$ & 42.7 & 8.5 & 48.8 & 1.78 & 0.134 & $\ldots$ & 2.1 & 1.5 & 1.0 & 6.4 & $\ldots$ & 4.3 & 5.6 \\
\hline \multirow{2}{*}{ Byumba } & Kibare & $0-37$ & 21.1 & 31.1 & 47.8 & 1.11 & 0.119 & $\ldots$ & 2.9 & 1.0 & 0.2 & 5.1 & & 7.1 & 5.7 \\
\hline & Gitusa & $0-10$ & 34.4 & 8.8 & 56.8 & 1.89 & 0.127 & $\ldots$ & 4.8 & 2.7 & 0.8 & 6.9 & $\ldots$ & 9.6 & 6.5 \\
\hline \multirow[t]{2}{*}{ Ruhengeri } & Nshabingo & $0-33$ & 37.8 & 34.2 & 28.0 & 2.81 & 0.251 & $\ldots$ & 0.1 & 0.1 & 0.3 & 23.5 & 4.6 & 14.4 & 4.4 \\
\hline & Kigombe & $0-14$ & 7.5 & 37.0 & 55.5 & 1.20 & 0.115 & $\ldots$ & 6.6 & 1.4 & 0.5 & 5.6 & $\ldots$ & 10.3 & 6.2 \\
\hline Gisenyi & Muturea & $0-11$ & 11.4 & 71.2 & 17.4 & 9.75 & 0.996 & $\ldots$ & 38.4 & 6.3 & 0.3 & 45.1 & $\ldots$ & 68.2 & 6.5 \\
\hline \multirow[t]{3}{*}{ Kibungo } & Kayonza & $0-30$ & 10.2 & 13.6 & 76.2 & 0.48 & 0.054 & $\ldots$ & 1.6 & 1.0 & 0.2 & 4.3 & & 3.5 & 6.0 \\
\hline & Kayonza & $0-16$ & 22.7 & 16.4 & 60.9 & 1.23 & 0.113 & $\ldots$ & 2.7 & 1.5 & 0.9 & 7.8 & $\ldots$ & 7.4 & 5.7 \\
\hline & Rutonde & $0-20$ & 43.3 & 6.9 & 49.8 & 1.75 & 0.114 & $\ldots$ & 3.3 & 0.9 & 0.1 & 8.9 & 0.3 & 9.8 & 5.3 \\
\hline
\end{tabular}

a Data from U.S. Department of Agriculture, Soil Conservation Service, Soil Survey Laboratory, National Soil Survey Center, Lincoln, NE.

${ }^{\mathrm{b}}$ Extractable.

c $\mathrm{NH}_{4} \mathrm{OAC}$ extractable. $\mathrm{CEC}=$ cation exchange capacity.

${ }^{\mathrm{d}}$ Data not taken. 
grains were placed adjacent to the bean seed being tested. Sclerotia were used as inoculum for $S$. rolfsii and were placed on the soil surface around the bases of 10-dayold plants. Inoculation with $F$. oxysporum f. sp. phaseoli was done by the root dip method. Ten-day-old plants grown on pasteurized perlite were carefully uprooted. The tips of roots were trimmed with scissors, dipped into a spore suspension $\left(10^{6}\right.$ conidia per milliliter) for $3 \mathrm{~min}$, and transplanted in pasteurized soil (2). Plants (three to four per pot, three pots per isolate) inoculated with Pythium spp., $R$. solani, and $S$. rolfsii received water daily for 10 days after inoculation and every 3 days thereafter. Pots with $M$. phaseolina and $F$. oxysporum f. sp. phaseoli received water every 3 days. Homogenized water agar placed at the bases of bean seedlings served as a control for Pythium spp. Uncolonized, autoclaved rice was used in controls for $M$. phaseolina and $R$. solani, while noninoculated seedlings served as controls for $S$. rolfsii and $F$. oxysporum f. sp. phaseoli. Temperatures in the greenhouse where plants were kept varied from 19 to $28^{\circ} \mathrm{C}$. Twenty isolates of $M$. phaseolina, 20 of S. rolfsii, 60 of Pythium spp., and 80 of $F$. oxysporum f. sp. phaseoli were tested for pathogenicity. Symptoms were recorded 3 to 4 weeks after inoculation.

\section{RESULTS}

Identification and pathogenicity tests. Symptoms observed on infected plants included necrotic lesions on the hypocotyls and main and secondary roots; watersoaked areas on the hypocotyls; collapse of the taproots; decay of secondary roots; brown sunken cankers on taproots; brown vascular discoloration; and in some cases, pink coloration of the hypocotyl pith. Soilborne pathogens associated with these symptoms were Pythium spp., R. solani, F. oxysporum f. sp. phaseoli, and $S$. rolfsii. Inoculation with the different pathogens resulted in symptoms similar to those observed on bean plants growing in naturally infested soil in the field. Seedlings inoculated with $M$. phaseolina showed dark lesions on the cotyledons and/or stem tissues; and later, young leaves developed systemic chlorosis. Reddish brown, sunken cankers were observed on taproots and lower stems of seedlings inoculated with $R$. solani. S. rolfsii induced water-soaked lesions that subsequently turned dark brown on lower stem and taproot tissues. Later, infected plants wilted, and mycelia were observed on affected tissues. $P y$ thium spp. induced decay of fibrous roots, water-soaked lesions, and eventually the collapse of the lower stems and roots. Most of the $F$. oxysporum f. sp. phaseoli isolates induced only general chlorosis. A few isolates caused defoliation and wilting of the plants. The vascular systems of these plants showed varied degrees of discoloration. No symptoms were observed on control plants.

Spatial and seasonal distribution. Of the approximately 1,620 plant samples collected per prefecture during the March through June 1989 season, more than 97\% exhibited at least some of the symptoms associated with infection by soilborne fungal pathogens (Table 2). No symptoms of nematode injury were observed. Of the samples collected, $15 \%$ were also infested with pupae of the bean stem maggot (Ophiomyia spp.), the most important insect pest of common bean in Africa. Almost 3\% of all samples with no root or hypocotyl symptoms were infested with the bean stem maggot. Fungi isolated included Pythium spp., M. phaseolina, R. solani, and $F$. oxysporum f. sp. phaseoli. Pythium spp. were the predominant fungi in samples from all four prefectures. They were isolated from more than $40 \%$ of the plants sampled from Kigali, Gikongoro, and Cyangugu prefectures and from $15 \%$ from Kibuye (Fig. 2A). M. phaseolina was the second most common fungus isolated in three prefectures; the highest levels (19.4\%) were observed in Kigali. Although all fungi were isolated from all seven prefectures, their distribution within communes and sectors was uneven. For example, the Fusarium wilt pathogen was isolated in samples from only one commune in northern Kigali, while $R$. solani was not found in samples from communes Tare (Gikongoro) or Mwenda (Kibuye). Although occurrence of two or more pathogen groups from the same area was high (Fig. 2), the frequency of their isolation from the same plant was low. During the survey of the March through June 1989 season, Pythium spp. and R. solani were isolated from 2 and $3 \%$ of the samples from Kigali and Cyangugu, respectively. Similarly, $R$. solani and $M$. phaseolina were isolated from 2 and $3 \%$ of the samples from Cyangugu and Gikongoro, respectively, while $R$. solani and Fusarium were isolated from 3\% and Pythium and Fusarium spp. from $2 \%$ of the samples from Cyangugu. Common saprophytes, including Penicillium spp., Rhizopus spp., Chaetomium spp., F. moniliforme, and $F$. semitectum, were also isolated.

Samples were taken at each of four plant growth stages in Kigali, Butare, Gikon-

Table 2. Percentage of bean plants showing root rot symptoms or bean stem maggot during the March through June 1989 season from four prefectures in Rwanda ${ }^{\mathrm{a}}$

\begin{tabular}{lccc}
\hline Prefecture & Root rots & $\begin{array}{c}\text { Root rots and } \\
\text { bean stem maggot }\end{array}$ & $\begin{array}{c}\text { Bean stem } \\
\text { maggot alone }\end{array}$ \\
\hline Kigali & 100.0 & 20.0 & 0.0 \\
Cyangugu & 98.8 & 0.2 & 1.0 \\
Gikongoro & 96.6 & 31.5 & 3.4 \\
Kibuye & 93.3 & 9.7 & 6.7 \\
Mean & 97.2 & 15.4 & 2.7 \\
\hline
\end{tabular}

a Plants (1,620 per prefecture) were examined for symptoms associated with soilborne pathogens on roots and hypocotyls. goro, and Cyangugu during the September through December 1989 season and in Gisenyi and Kibungo during the March through June 1990 season. On average, the percentage of plants showing root rot symptoms increased from 17 at the first trifoliate stage (V3) to 70 at pod maturation (R8). At the beginning of flowering (R5), $19 \%$ of the plants in Kigali showed root rot symptoms, $40 \%$ in Butare, 33\% in Gikongoro, $33 \%$ in Cyangugu, $60 \%$ in Gisenyi, and 53\% in Kibungo.

As during the March through June 1989 season, Pythium spp. were the predominant fungi $(41 \%)$ isolated from the different prefectures followed by $M$. phaseolina (17.7\%), F. oxysporum f. sp. phaseoli (11.7\%), and $R$. solani (8.2\%) (Fig. 2B). Also, Pythium spp. were the fungi most frequently isolated at all plant growth stages (data not shown). R. solani was isolated more frequently at the V3 and V4 growth stages (14\%) than at R6 and R7 (7\%). Several common soil saprophytes were also isolated. On the basis of plant mortality and root rot severity, it was determined that commonly grown local bush varietal mixtures with a determinate growth habit were more affected by root rots than climbing types with an indeterminate growth habit.

During the September through December 1990 season, five pathogens were isolated from the 16 IBRRN entries (Fig. 2C). S. rolfsii was isolated in addition to the group of four pathogens isolated during the previous seasons. The frequency of isolation of pathogens was lower than in previous seasons and varied according to pathogen and prefecture. F. oxysporum f. sp. phaseoli was the predominant pathogen in Kigali, Butare, and Gikongoro; Pythium spp. were most frequently isolated only in Cyangugu. $R$. solani was isolated from a few plants in all seven prefectures.

Although a previous preliminary report (7) linked Fusarium and Rhizoctonia spp. with the outbreak of root rots in beans in Rwanda and Burundi, our results are the first to establish that Pythium spp., $R$. solani, M. phaseolina, $F$. oxysporum f. sp. phaseoli, and S. rolfsii are associated with these root rots. The fact that most of the pathogens were isolated during all four

\section{DISCUSSION}


seasons and from other prefectures not included in this study emphasizes their importance and widespread distribution in Rwanda. Except for $S$. rolfsii, all isolated fungi were found in all seven prefectures during all four seasons. The frequency of their isolation, however, varied from region to region and from season to season. These results agree with other reports on the incidence and severity of root rots in Rwanda (15)

Pythium spp. were the most frequently isolated fungi. Pythium spp. reported to be important on beans include $P$. ultimum Trow, $P$. irregulare Buisman, $P$. aphanidermatum (Edson) Fitzp., and P. myriotylum Drechs. (2,3,14). We did not identify Pythium at the species level, proving only
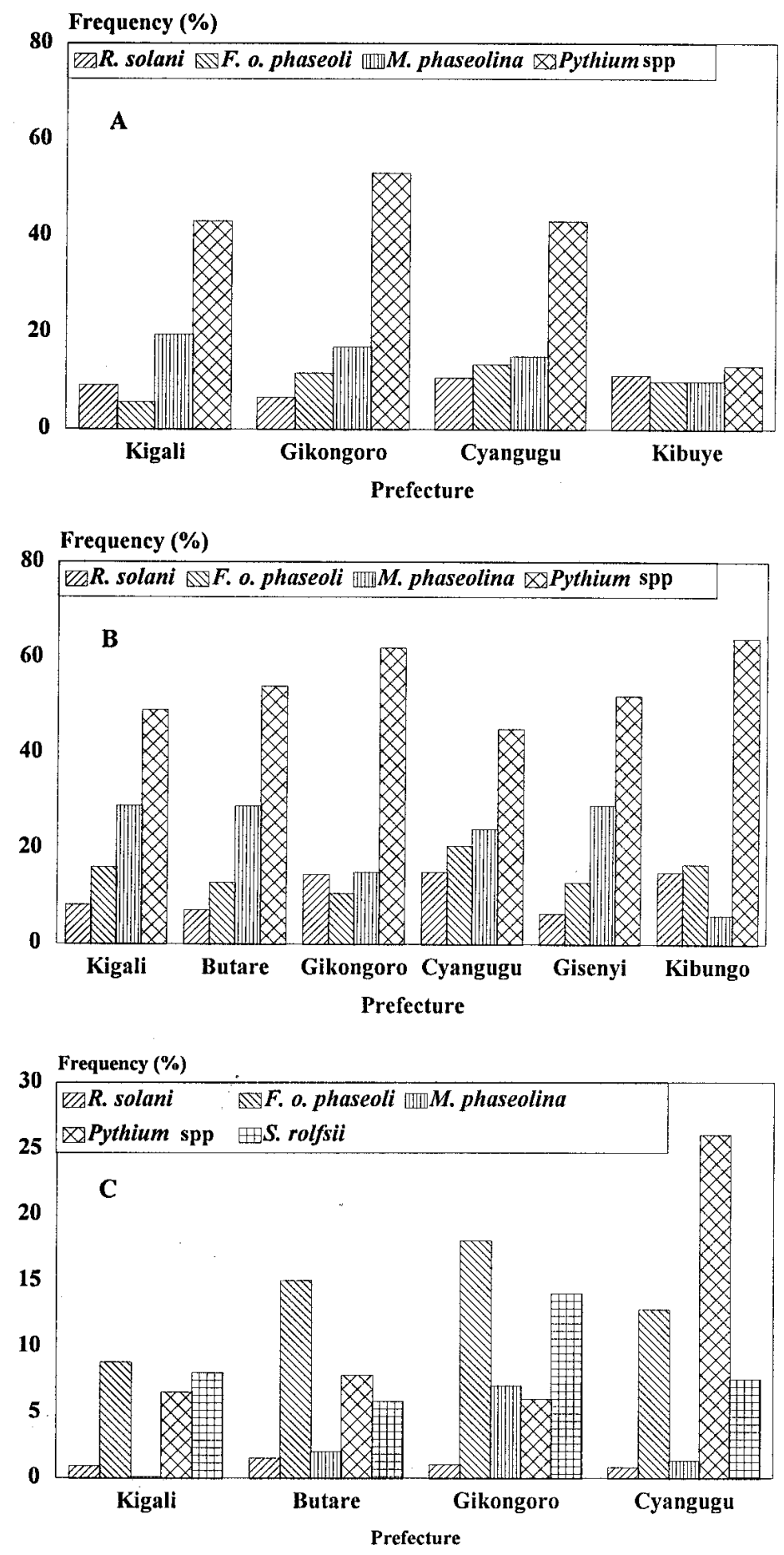

Fig. 2. Frequency (\%) of isolation of Rhizoctonia solani, Fusarium oxysporum f. sp. phaseoli, Macrophomina phaseolina, Pythium spp., and Sclerotium rolfsii from common bean samples in seven prefectures of Rwanda. (A) $n=1,620$ plant samples per prefecture during the March through June 1989 season; (B) $n=720$ plant samples per prefecture during the September through December 1989 season in Kigali, Butare, Gikongoro, and Cyangugu and during the March through June 1990 season in Gisenyi and Kibungo; and (C) $n=216$ plant samples per prefecture during the September through December 1990 season.

the pathogenicity of specific isolates. High soil water levels create an environment very favorable to Pythium spp. and their damage to beans (14). However, the effect of temperature varies according to the species involved (14). On the basis of isolation frequency, it can be concluded that Pythium spp. probably play an important role in the bean root rot complex problem in Rwanda. This may explain the results of trials over several seasons (R. Buruchara and G. Rusuku, unpublished data) and observations made by farmers that severe cases of root rot occur if rainfall is high while the crop is young (2 to 3 weeks after planting). Symptoms caused by Pythium spp. are commonly observed during such conditions (9) and are often later associated with Fusarium wilt.

Despite the relatively high isolation frequency of $M$. phaseolina, most of the symptoms associated with this fungus were mild, taking the form of sunken lesions on stem tissues below the soil surface. Infection of the stems above the soil, both in seedlings and mature plants, was less common; the prevailing rainy conditions were unfavorable for disease development. $F$. oxysporum f. sp. phaseoli and $R$. solani were isolated with relatively lower but regular frequency over sites and seasons.

Annual bean production in Rwanda has been declining since 1986 (18), partly because of the increase in the incidence and severity of root rots $(8,15)$. Intensified food production has inevitably led to ineffective crop rotation or fallowing. Continuous cropping of beans or a one-season rotation with another crop is a common practice in Rwanda and may have exacerbated the root rot problem. Growing other host crops such as sorghum, peas, soybeans, or groundnut $(13,21,22)$ in rotation or in association with beans may also contribute to the problems caused by pathogens such as Pythium spp., M. phaseolina, and $R$. solani. Sorghum, for example, is a major annual crop for the March through June season (when rainfall is high) and is alternated with beans, the principal crop for the September through December season. The importance of the role of these other host crops in the epidemiology of root rots of beans is not known but is believed to be considerable, especially in favoring pathogen survival and high inoculum densities.

Despite the low levels but widespread occurrence of $F$. oxysporum f. sp. phaseoli observed in these studies, recent evidence suggests that the incidence of Fusarium wilt is increasing in Rwanda, particularly in Gikongoro, Butare, and Cyangugu (9). Preliminary work (R. Buruchara, unpublished data) indicates this is partly because of increasing inoculum levels and changing patterns of interaction among pathogens in the root rot complex. For example, in sorghum attacked by Pythium spp., Fusarium spp. and other fungi are rapid secondary 
colonizers (19); and in peanuts, synergism among pathogens occurs (12). The frequent association of several soilborne pathogens in diseased bean roots needs investigation to determine whether these organisms cause disease in succession and to what extent synergism occurs.

Our results should help better target efforts to develop strategies for managing root rots in Rwanda. Use of resistant cultivars is the most effective strategy and the most appropriate for farmers who have small farms and limited resources. At CIAT, bean germ plasm has been identified with resistance or tolerance to specific root rot pathogens and could form the basis for developing resistance to the root rot pathogen complex occurring in Rwanda. However, the existence of the complex and the widespread practice of growing mixtures of bean cultivars means identifying and developing cultural methods for use in the short term and as a complementary component in the integrated management of root rots.

\section{ACKNOWLEDGMENTS}

We thank David Allen for reviewing the manuscript and Elizabeth de Paez for editing it.

\section{LITERATURE CITED}

1. Abawi, G. S. 1989. Root rots. Pages 105-157 in: Bean Production Problems in the Tropics. 2nd ed. H. F. Schwartz and M. A. PastorCorrales, eds. Centro Internacional de Agricultura Tropical, Cali, Colombia.

2. Abawi, G. S., and Pastor-Corrales, M. A. 1990. Root Rots of Beans in Latin America and Africa: Diagnosis, Research Methodologies, and Management Strategies. Centro Internacional de Agricultura Tropical, Cali, Colombia.

3. Adegbola, M. O. K., and Hagedorn, D. J. 1969. Symptomatology and epidemiology of
Pythium blight of bean. Phytopathology 60: 1477-1479.

4. Anonymous. 1992. Primary soil characterization data, Republic of Rwanda. USDA, Soil Conservation Service, Soil Survey Laboratory, National Soil Survey Center, Lincoln, NE.

5. Booth, C. 1971. The Genus Fusarium. Commonwealth Mycological Institute, Kew, England.

6. Centro Internacional de Agricultura Tropical. 1986. Bean diagnostic surveys. Pages 260276 in: Annual Report, Bean Program. CIAT, Cali, Colombia.

7. Centro Internacional de Agricultura Tropical. 1988. Plant protection. Pages 312-318 in: Annual Report, Bean Program. CIAT, Cali, Colombia.

8. Centro Internacional de Agricultura Tropical. 1990. Root rots. Pages 112-116 in: Annual Report, Bean Program. CIAT, Cali, Colombia.

9. Centro Internacional de Agricultura Tropical 1992. Root rots. Pages 119-131 in: Annual Report, Bean Program. CIAT, Cali, Colombia.

10. Clay, D. C. and Magnani, R. J. 1987. The human ecology of farming systems: Towards understanding agricultural development in Rwanda. Res. Rural Sociol. Dev. 3:141-167.

11. Ellis, M. B. 1971. Dematiaceous Hyphomycetes. Commonwealth Mycological Institute, Kew, England.

12. Garcia, R., and Mitchell, D. J. 1975. Synergistic interactions of Pythium myriotylum with Fusarium solani and Meloidogyne arenaria in pod rot of peanuts. Phytopathology 65:832833.

13. Hagedorn, D. J., ed. 1984. Compendium of Pea Diseases. American Phytopathology Society, St. Paul, MN.

14. Hoch, H. C. 1975. Role of Pythium spp. as incitant of bean and hypocotyl rot in Wisconsin. Plant Dis. Rep. 59:443-447.

15. Institut des Sciences Agronomiques du Rwanda. 1990. Rapport Annuel, 1990. ISAR, Rubona, Rwanda.

16. Ministère du Plan. 1988. Enquête National sur le Budget et la Consommation des Ménages. Vol. 4, Consommation Alimentaire au Millieu Rural. MP, Kigali, Rwanda.
17. Neel, H., De Prins, H., and Vindevogel, E. 1976. Etude de la fertilite des sols a l'aide des vases de vegetation. Note Technique 1 . Institut des Sciences Agronomiques du Rwanda, Rubona.

18. Ngirumwami, J. L. 1992. Analysis of food crop production and marketing trends in Rwanda with emphasis on dry beans. M.S. thesis Michigan State University, East Lansing.

19. Odvody, G. N, and Forbes, G. 1984. Pythium root and seedling rots. Pages 31-35 in: Sorghum Root and Stalk Rots, A Critical Review. Proc. Consult. Group Discuss. Res. Needs Strategies Control Sorghum Root Stalk Rot Dis. International Crops Research Institute for the Semi-Arid Tropics, Patancheru, India.

20. Pachico, D. 1993. The demand for bean technology. Pages 60-73 in: Trends in CIAT Commodities. G. Henry, ed. Work. doc. 128 Centro Internacional de Agricultura Tropical, Cali, Colombia.

21. Porter, D. M., Smith, D. H., and RodríguezKabana, R. 1984. Compendium of Peanut Diseases. 1st ed. American Phytopathological Society, St. Paul, MN.

22. Pratt, R. G., and Janke, G. D. 1980. Pathogenicity of three species of Pythium to seedlings and mature plants of grain sorghum. Phytopathology 70:766-771.

23. Trutmann, P., and Graf, W. 1987. Les facteurs agronomiques limitant la production du haricot commun au Rwanda et les stratégies de leur maîtrise. Pages 157-161 in: Seminaire sur le Maladies et les Ravageurs des Principales Cultures Vivriers d'Afrique Centrale. IRAZISABU, CTA Serv. Agric. Rurale Publ. 15.

24. van Schoonhoven, A., and Pastor-Corrales, M. A. 1987. Standard System for the Evaluation of Bean Germplasm. Centro Internacional de Agricultura Tropical, Cali, Colombia.

25. Waterhouse, G. M. 1968. The genus Pythium. Mycol. Pap. 110. Commonwealth Mycological Institute, Kew, England.

26. Wortmann, C. S., and Allen, D. J. 1994 African bean production environments: Their definition, characteristics, and constraints. Network on Bean Research in Africa. Occasional paper series 11. Centro Internacional de Agricultura Tropical, Cali, Colombia. 